\title{
Treatment and outcome of toxic epidermal necrolysis in 32 Chinese patients: a hospital- based study
}

\author{
Ting Xiao ${ }^{1 *}$, Li-Ming Zhang², Yan Zhao \\ From 6th Drug Hypersensitivity Meeting (DHM 6) \\ Bern, Switzerland. 9-12 April 2014
}

\section{Background}

Toxic epidermal necrolysis (TEN), the most severe drug reaction, has been reported to be associated with considerable mortality rate. In the past 15 years, the use of intravenous immunoglobulin (IVIG) have improved the prognosis of TEN.

\section{Method}

We retrospectively studied 32 patients with TEN in a Chinese tertiary medical center between July 1, 2008 and June 30, 2013 to evaluate the clinical manifestations, laboratory tests, treatment of TEN and prognostic factors for the mortality of TEN.

\section{Results}

Antibiotics $(\mathrm{n}=12)$ were the most common offending drugs, followed by non-steroidal anti-inflammatory drugs $(\mathrm{n}=8)$, anti-rheumatic drugs $(\mathrm{n}=2)$ and Chinese herbs $(\mathrm{n}=2)$. Hypertension $(34.4 \%, \mathrm{n}=11)$ and diabetes $(21.9 \%$, $\mathrm{n}=7$ ) were the most common pre-existing conditions. Hepatitis B virus infection, cerebrovascular diseases and cardiovascular diseases pre-existed in $15.6 \%(n=5), 12.5 \%$ $(n=4)$ and $12.5 \%(n=4)$ of the 32 patients, respectively. TEN showed higher incidence in the patients with HBV infection. All 32 patients were treated initially with systemic corticosteroids ranging from $50 \mathrm{mg}$ to $150 \mathrm{mg}$ daily. Sixteen patients were treated with combined IVIG (400 mg/kg/day, for 5 days). Twenty-nine patients were cured without or with different sequelae. The mortality rate was $9.38 \%(n=3)$. The application of IVIG reduced the estimated mortality of TEN to $17 \%$. Delayed use of IVIG, elevated level of urea nitrogen and early onset of

${ }^{1}$ The First Affiliated Hospital of China Medical University, China Full list of author information is available at the end of the article

the rashes after taking offensive drugs were associated with the mortality of TEN.

\section{Conclusion}

Systemic corticosteroids in combination with IVIG were effective for TEN in Chinese patients. TEN showed higher incidence in Chinese patients with HBV infection. Delayed use of IVIG, elevated level of urea nitrogen and early onset of the rashes after taking offensive drugs correlated with poor prognosis of TEN.

\section{Authors' details}

${ }^{1}$ The First Affiliated Hospital of China Medical University, China. ${ }^{2}$ The First Affiliated Hospital of China Medical University, Dermatology, China.

Published: 18 July 2014

\section{doi:10.1186/2045-7022-4-S3-P10}

Cite this article as: Xiao et al.: Treatment and outcome of toxic epidermal necrolysis in 32 Chinese patients: a hospital-based study. Clinical and Translational Allergy 2014 4(Suppl 3):P10.

Submit your next manuscript to BioMed Central and take full advantage of:

- Convenient online submission

- Thorough peer review

- No space constraints or color figure charges

- Immediate publication on acceptance

- Inclusion in PubMed, CAS, Scopus and Google Scholar

- Research which is freely available for redistribution
C Biomed Central

(C) 2014 Xiao et al; licensee BioMed Central Ltd. This is an Open Access article distributed under the terms of the Creative Commons Attribution License (http://creativecommons.org/licenses/by/4.0), which permits unrestricted use, distribution, and reproduction in any medium, provided the original work is properly cited. The Creative Commons Public Domain Dedication waiver (http://creativecommons.org/publicdomain/zero/1.0/) applies to the data made available in this article, unless otherwise stated. 